\title{
Ginsenoside Rg3 inhibits keloid fibroblast proliferation, angiogenesis and collagen synthesis in vitro via the TGF-p/Smad and ERK signaling pathways
}

\author{
MENGYAO TANG* , WEIWEI BIAN* , LIYING CHENG, LU ZHANG, \\ RONG JIN, WENBO WANG and YUGUANG ZHANG \\ Department of Plastic and Reconstructive Surgery, Shanghai Ninth People's Hospital \\ Affiliated Shanghai Jiao Tong University School of Medicine, Shanghai 200011, P.R. China
}

Received November 15, 2016; Accepted December 15, 2017

DOI: $10.3892 /$ ijmm.2018.3362

\begin{abstract}
A wide range of therapeutic options exists for the treatment of keloids, all of which have their own strengths; however, a high risk of side-effects and frequent recurrence remains. Therefore, the present study aimed to identify improved therapeutic approaches or drugs for the treatment of keloids. Ginsenoside $\mathrm{Rg} 3$ (Rg3) has been reported to exert numerous antitumor effects, thus indicating that $\operatorname{Rg} 3$ may be a potential therapeutic agent that targets keloids. The present study determined the effects of $\mathrm{Rg} 3$ on human keloid fibroblasts (KFs) in vitro, and further explored the associated molecular and cellular mechanisms. Keloid scar specimens were obtained from patients, aged between 22 and 35 years, without systemic diseases and primary cells were isolated from keloid tissues. In each assay, KFs were divided into three groups and were cultured in medium with or without various concentrations of $\operatorname{Rg} 3$ (50 or $100 \mu \mathrm{g} / \mathrm{ml}$ ). Cell viability assay, flow cytometry, quantitative polymerase chain reaction, cell migration assay, immunofluorescence staining, western blot analysis, Transwell cell invasion assay and immunohistochemical analysis were used to analyze the KFs and keloid explant cultures. The results of the present study demonstrated that $\mathrm{Rg} 3$ was able to exert an inhibitory effect on the transforming growth factor- $\beta / \mathrm{Smad}$ and extracellular signal-regulated kinase signaling pathways in KFs. The proliferation, migration, invasion, angiogenesis and collagen synthesis of KFs were markedly suppressed following treatment with $\operatorname{Rg} 3$. Furthermore, the results of an ex vivo assay indicated that $\mathrm{Rg} 3$ inhibited angiogenesis and reduced collagen
\end{abstract}

Correspondence to: Dr Yuguang Zhang or Dr Wenbo Wang, Department of Plastic and Reconstructive Surgery, Shanghai Ninth People's Hospital Affiliated Shanghai Jiao Tong University School of Medicine, 639 Zhizaoju Road, Shanghai 200011, P.R. China

E-mail: zhangyg18@126.com

E-mail: wangwenbo0903@126.com

*Contributed equally

Key words: wound healing, keloid, ginsenoside Rg3, signaling pathways accumulation in keloids. Significant statistical differences existed between the control and $\mathrm{Rg} 3$-treated groups $(\mathrm{P}<0.05)$. All of these experimental results suggested that $\mathrm{Rg} 3$ may serve as a reliable drug for the treatment of patients with keloids.

\section{Introduction}

Abnormal wound healing processes are present in keloids, including excessive scarring, hyperproliferation of fibroblasts and overabundant deposition of extracellular matrix (ECM) components (1). Keloids have been reported to occur after a certain degree or type of skin wound (2). Although the pathogenesis of keloids remains obscure, it has previously been indicated that it involves aberrant cell activities and intricate signaling pathways between various cellular populations (3). The clinical features of keloids are as follows: i) Keloid scars exceed the original margins and invade adjacent healthy tissue, thus behaving similarly to 'invasive' benign skin tumors; ii) keloids seldom exhibit expected regression with time; iii) keloids usually recur following regular treatment (4). Butler et al (5) presented four histological features specific for keloids: i) Peculiar hyalinized and eosinophilic collagen in keloids; ii) tongue-like advancing edge underneath normal-appearing epidermis and papillary dermis; iii) horizontal cellular fibrous bands in the upper reticular dermis; iv) prominent fascia-like fibrous bands.

Keloids are often associated with pain and pruritus, and are considered unsightly; therefore, they may affect patients' mood and have an impact on quality of life. At present, there are numerous multilevel therapies available for the treatment of keloids, including silicon membrane, intralesional corticosteroid or 5-fluorouracil injections, and cryosurgery or conventional surgery with additional corticosteroids treatment or radiotherapy (6). Although a wide range of therapeutic options exists for keloid treatment, all of which have their own strengths, a high risk of side-effects and frequent recurrence remains (7). Therefore, it is urgent and of great importance to identify improved therapeutic approaches or drugs for the treatment of keloids.

Ginsenoside $\operatorname{Rg} 3$ ( $\operatorname{Rg} 3$ ) is a traditional Chinese medicine, which is extracted from Panax ginseng. The pharmacological components of ginseng include ginsenosides, triterpene glycosides and secondary metabolites. There are two optical isomers 
of $\operatorname{Rg} 3$, named 20R-Rg3 and 20S-Rg3, which result in different hydroxyl positions at carbon-20. It has been suggested that $\operatorname{Rg} 3$ exerts numerous biological activities, and has a wide range of clinical and pharmacological effects (8). A previous study indicated that $\operatorname{Rg} 3$ may inhibit the proliferation of several types of tumor cell and may induce apoptosis (9). The anticarcinogenic effects of $\operatorname{Rg} 3$ have been demonstrated in vitro and in vivo. He et al (10) reported that the proliferation of colorectal cancer cells was inhibited by $\operatorname{Rg} 3$ via the Wnt/ $\beta$-catenin pathway. Wang et al (11) revealed that Rg3 can induce the apoptosis of ovarian cancer cells by inhibiting the phosphoinositide 3-kinase/protein kinase B pathway. Previous studies have also reported that $\operatorname{Rg} 3$ may decrease angiogenesis in tumors via the downregulation of the cytokine vascular endothelial growth factor (VEGF) (12) or via a shortage of oxygen (13).

Due to the tumor-like biological features of keloids and the characteristics of $\mathrm{Rg} 3$, particularly the numerous antitumor effects, it has been suggested that $\operatorname{Rg} 3$ may be a potential therapeutic agent that targets keloids. Although Pazyar et al (14) reported that ginseng was effective against keloid scarring, this was an indirect conclusion deduced from other studies, which did not directly investigate the effects of ginseng on keloids, but investigated the molecular mechanisms underlying keloid formation and the effects of ginseng on other cell lines. Furthermore, no specific empirical data was provided. The present study aimed to be the first, to the best of our knowledge, to investigate the effects of $\mathrm{Rg} 3$ on human keloid fibroblasts $(\mathrm{KFs})$ in vitro, and to explore the related molecular and cellular mechanisms.

\section{Materials and methods}

Materials and chemicals. Rg3 (purity, 98.6\%) was purchased from Dalian Fusheng Pharmaceutical, Ltd. (Dalian, China). $\mathrm{Rg} 3$ was dissolved in dimethyl sulfoxide (DMSO) and filtered through a $0.22 \mu \mathrm{m}$ bacterial filter. The mixture was then diluted with Dulbecco's modified Eagle's medium (DMEM; Gibco; Thermo Fisher Scientific, Inc., Waltham, MA, USA) containing $10 \%$ fetal bovine serum (FBS; HyClone; GE Healthcare Life Sciences, Logan, UT, USA) to form the final concentrations (50 or $100 \mu \mathrm{g} / \mathrm{ml}$ ). The final concentrations of $\mathrm{Rg} 3$ were selected according to previous studies and based on existing data regarding the effective dose $(15,16)$. The final concentrations of DMSO in the culture medium were $<0.1 \%$.

Subjects. A total of 15 Asian patients with keloids were recruited to the present study. Keloid scar specimens were obtained from these patients, which were aged between 22 and 35 years old, without systemic diseases. All patient information is provided in Table I. The lesions were diagnosed as keloids according to clinical appearance, symptoms, persistence for $>1$ year and extension beyond the original margins. All of the patients' keloids were in the active stage and none had undergone prior treatment. Prior to surgery, all patients were informed of the purpose and procedure of the present study and agreed to provide their resected lesion masses. The whole keloid tissues were completely removed, following administration of local anesthesia, from the skin of the neck, chest, abdomen and upper limb, according to the standard surgical procedures. Prior written informed consent was obtained from all participants and the present study was approved by the Ethics Committee of
Table I. Patient and keloid specimen information.

\begin{tabular}{lcccc}
\hline $\begin{array}{l}\text { Sample } \\
\text { no. }\end{array}$ & Gender & Ethnic group & $\begin{array}{c}\text { Age } \\
\text { (years) }\end{array}$ & $\begin{array}{c}\text { Size of } \\
\text { sample }\left(\mathrm{cm}^{2}\right)\end{array}$ \\
\hline S1 & M & Asian & 23 & $8 \times 3$ \\
S2 & M & Asian & 33 & $2 \times 4$ \\
S3 & M & Asian & 22 & $5 \times 3$ \\
S4 & F & Asian & 23 & $4 \times 3$ \\
S5 & M & Asian & 23 & $4 \times 2$ \\
S6 & M & Asian & 25 & $7 \times 1$ \\
S7 & F & Asian & 28 & $5 \times 2$ \\
S8 & F & Asian & 27 & $6 \times 1$ \\
S9 & M & Asian & 30 & $5.5 \times 3$ \\
S10 & M & Asian & 31 & $3.5 \times 4$ \\
S11 & M & Asian & 34 & $6 \times 2$ \\
S12 & F & Asian & 33 & $2 \times 1$ \\
S13 & F & Asian & 21 & $9 \times 2$ \\
S14 & F & Asian & 35 & $4.5 \times 2.5$ \\
S15 & M & Asian & 29 & $3 \times 2$ \\
\hline
\end{tabular}

F, female; M, male.

Shanghai Ninth People's Hospital affiliated Shanghai Jiao Tong University School of Medicine (Shanghai, China).

Culture of KFs. The adipose tissues and epidermis were removed from the samples using sterilized scissors; the remaining dermis was cut into $1 \mathrm{x} 1 \mathrm{~mm}$ sections and digested in $0.25 \%$ collagenase for $\sim 4 \mathrm{~h}$ at $37^{\circ} \mathrm{C}$. Following centrifugation at $300 \mathrm{x} \mathrm{g}$ at room temperature for $5 \mathrm{~min}$, the supernatant was discarded and the remaining precipitate, including abundant KFs and several pieces of dermis tissue was cultured in high glucose DMEM (Gibco; Thermo Fisher Scientific, Inc.) supplemented with $10 \%$ FBS, penicillin $(100 \mathrm{U} / \mathrm{ml})$ and streptomycin $(100 \mu \mathrm{g} / \mathrm{ml})$ (Sigma-Aldrich; Merck KGaA, Darmstadt, Germany) in $100 \mathrm{~mm}$ dishes at $37^{\circ} \mathrm{C}$ in a humidified incubator containing $5 \% \mathrm{CO}_{2}$. The culture media were replaced every 3 days. The fibroblasts gradually attached to the dish or migrated out of the small pieces of dermis tissue within 7-10 days. KFs between passages 2 and 4 were used in the present study.

Microscopic observation. The present study analyzed Rg3-induced cell death by observing morphological alterations. KFs were seeded in 6-well plates at a density of $8 \times 10^{4}$ cells/well and were cultured at $37^{\circ} \mathrm{C}$ in an atmosphere containing $5 \% \mathrm{CO}_{2}$. Medium with DMSO $(<0.1 \%)$ and with various concentrations of $\operatorname{Rg} 3$ (50 or $100 \mu \mathrm{g} / \mathrm{ml}$ ) was added to the grouped wells. Following a $72 \mathrm{~h}$ incubation at $37^{\circ} \mathrm{C}, \mathrm{KFs}$ in the various groups were observed and images were captured under an inverted microscope (Nikon IX70; Nikon Corporation, Tokyo, Japan).

Cell viability assay. The viability of KFs treated with or without Rg3 was determined using the Cell Counting kit-8 (CCK-8) assay (Dojindo Molecular Technologies, Inc., Kumamoto, Japan). The KFs were cultured in serum-free medium for $24 \mathrm{~h}$ for synchronization. Subsequently, the cells were incubated with 
DMEM containing 10\% FBS for the following experiments. KFs were seeded in 96-well plates at a density of $1 \times 10^{4}$ cells $/ \mathrm{ml}$ and were incubated overnight for $24 \mathrm{~h}$ at $37^{\circ} \mathrm{C}$ in an atmosphere containing $5 \% \mathrm{CO}_{2}$. Medium with various $\mathrm{Rg} 3$ concentrations (50 or $100 \mu \mathrm{g} / \mathrm{ml}$ ) was then added to the wells. After treatment for 1, 2, 3, 4 and 5 days, $10 \mu \mathrm{l}$ CCK-8 was added to each well, and the cells were incubated at $37^{\circ} \mathrm{C}$ for $2.5 \mathrm{~h}$ according to the manufacturer's protocol. Aliquots $(100 \mu \mathrm{l})$ of incubated medium were pipetted into a 96-well plate and colorimetric absorbance was recorded at $450 \mathrm{~nm}$ using a microplate reader (Thermo Labsystems, Helsinki, Finland).

Flow cytometry (FCM) analysis of Annexin V-fluorescein isothiocyanate (FITC) staining. The present study applied the FCM method to measure and analyze the rate of apoptosis according to the instructions provided by the Annexin V-FITC kit (Miltenyi Biotec GmbH, Bergisch Gladbach, Germany). The KFs were incubated in 6-well plates with medium containing various $\mathrm{Rg} 3$ concentrations (50 or $100 \mu \mathrm{g} / \mathrm{ml})$. Following a $72 \mathrm{~h}$ incubation at $37^{\circ} \mathrm{C}$, the KFs in each well were collected by centrifugation at $300 \mathrm{x} \mathrm{g}$ at room temperature for $5 \mathrm{~min}$ and washed twice with cold PBS. These cells were then resuspended in $500 \mu \mathrm{l}$ binding buffer, and incubated with $10 \mu \mathrm{l}$ Annexin V-FITC for $10 \mathrm{~min}$ at room temperature in the dark. Subsequently, $10 \mu$ propidium iodide was added to the cells for $10 \mathrm{~min}$ at room temperature in the dark; the reaction was terminated by chilling in an ice-bath. Analysis of apoptotic rate was conducted using a flow cytometer (BD Biosciences, San Jose, CA, USA); >10,000 cells from each well were counted and the apoptotic percentage, as well as the percentage of necrotic cell death, was quantitatively analyzed using CellQuest software 5.1 (BD Biosciences).

RNA isolation and quantitative polymerase chain reaction ( $q P C R)$. KFs were added to a $10 \mathrm{~cm}$ culture dish at a density of $5 \times 10^{4}$ cells $/ \mathrm{ml}$. After $48 \mathrm{~h}$, the medium was changed and the cells were cultured for $72 \mathrm{~h}$ in fresh medium with or without various Rg3 concentrations (50 or $100 \mu \mathrm{g} / \mathrm{ml}$ ). Subsequently, KFs were harvested and total RNA was extracted using TRIzol ${ }^{\circledR}$ reagent (Invitrogen; Thermo Fisher Scientific, Inc.). Reverse transcription was then performed; briefly, cDNA was synthesized from $2 \mu \mathrm{g}$ total RNA using oligo(dT) and AMV reverse transcriptase (Promega Corporation, Madison, WI, USA). The reverse transcription was conducted according to manufacturer's protocol. RNA integrity and the success of reverse transcription were monitored by qPCR amplification of GAPDH transcripts. qPCR was conducted using the Power SYBR-Green PCR master mix (2X) (Applied Biosystems; Thermo Fisher Scientific, Inc.) on a real-time thermal cycler $\left(\mathrm{Mx} 3000 \mathrm{P}^{\mathrm{TM}}\right.$ qPCR system; Agilent Technologies, Inc., Santa Clara, CA, USA). The mixture was incubated at $95^{\circ} \mathrm{C}$ for $10 \mathrm{~min}$, followed by 40 cycles $(30 \mathrm{sec}$ at $95^{\circ} \mathrm{C}, 30 \mathrm{sec}$ at annealing temperature listed in Table II), and was finally incubated at $72^{\circ} \mathrm{C}$ for $5 \mathrm{~min}$. The amplified products were normalized against the internal reference gene (GAPDH). GAPGH was amplified as an internal control, and relative gene expression analysis was performed using the $2^{-\Delta \Delta C q}$ method (17). The primers for qPCR analysis are listed in Table II.

Scratch wound assay. The scratch wound assay was used to evaluate the migration of KFs (18). Briefly, KFs ( $2 \times 10^{5}$ cells/well) were plated into 6 -well culture plates and were incubated until they reached $\sim 100 \%$ confluence. A scratch wound was generated on the cell monolayer using a sterile $200 \mu$ l pipette tip, in order to form a cell-free 'wound' $\sim 0.83 \pm 0.05 \mathrm{~mm}$ in width. The cell cultures were incubated with fresh medium containing various $\operatorname{Rg} 3$ concentrations (50 or $100 \mu \mathrm{g} / \mathrm{ml}$ ). Digital images of each wound were captured under a Nikon Eclipse E200 microscope (Nikon Corporation) immediately $(0 \mathrm{~h})$, and 24 and $48 \mathrm{~h}$ after scratch generation. Cell migration was analyzed using the commercial software Image Pro-Plus version 6.0 (Media Cybernetics, Inc., Rockville, MD, USA). Data (means \pm standard deviation, $n=3$ ) are expressed as the percentage of the scratched cell-free zone filled with KFs. For each sample, images were captured from three random views to obtain the mean value. The final mean percentages and standard deviation were determined from three KF samples.

Immunofluorescence staining for type I collagen, $\alpha$-smooth muscle actin ( $\alpha$-SMA) and $\mathrm{Ki}-67$ expression. KFs were grown in 6 -well plates at a density of $2 \times 10^{4}$ cells $/ \mathrm{ml}$. Following incubation for $24-36 \mathrm{~h}$ at $37^{\circ} \mathrm{C}$ in an atmosphere containing $5 \% \mathrm{CO}_{2}$, medium with or without various $\mathrm{Rg} 3$ concentrations (50 or $100 \mu \mathrm{g} / \mathrm{ml}$ ) was added to the wells. After $72 \mathrm{~h}$, KFs were fixed with $4 \%$ paraformaldehyde at $4{ }^{\circ} \mathrm{C}$ overnight and permeabilized using $0.3 \%$ Triton $\mathrm{X}-100$ at room temperature for $1 \mathrm{~h}$. Nonspecific binding sites were blocked with normal goat serum (Sigma-Aldrich; Merck KGaA) at $37^{\circ} \mathrm{C}$ for $30 \mathrm{~min}$. Subsequently, the KFs were incubated overnight at $4^{\circ} \mathrm{C}$ with primary rabbit anti-human antibodies against type I collagen (1:500; ab34710), $\alpha$-SMA (1:100; ab5694) and Ki-67 (1:1,000; ab15580) (Abcam, Cambridge, MA, USA). Subsequently, the cells were incubated with appropriate fluorescent goat anti-rabbit secondary antibodies (111-035-003; Jackson Immunoresearch Laboratories, Inc., West Grove, PA, USA) at room temperature for $1 \mathrm{~h}$. DAPI was used to stain the nuclei prior to image acquisition. Images of the positive cells (green) and DAPI nuclear staining (blue) were captured using a fluorescence microscope (Olympus Corporation, Tokyo, Japan). The incorporation ratio of Ki-67-positive cells was determined using the following equation: Number of Ki-67-positive cells/number of total cells. The results were counted in five randomly selected fields.

Western blot analysis. Western blot analysis was performed as described previously (19), using primary antibodies specific for type I collagen, type III collagen, fibronectin, phosphorylated (p)-Smad2, p-Smad3, total-Smad2/3, Smad7, p-extracellular signal-regulated kinase (ERK)1/2 and total-ERK1/2 (all purchased from Cell Signaling Technology, Inc., Danvers, MA, USA). Briefly, tissues were collected, and total cellular protein was extracted in $100 \mu 1$ RIPA lysis buffer (Beyotime, Shanghai, China) supplemented with $1 \mathrm{mM}$ phenylmethylsulfonyl fluoride (PMSF) (Beyotime) and $50 \mu \mathrm{l} / \mathrm{ml}$ protease inhibitor cocktail (Sigma-Aldrich; Merck KGaA) at $4^{\circ} \mathrm{C}$ for $30 \mathrm{~min}$. Protein concentration was measured using the bicinchoninic acid (BCA) method. Samples containing $20 \mu \mathrm{g}$ protein $(2 \mu \mathrm{g} /$ $\mu 1)$ were boiled, subjected to SDS-PAGE on $10 \%$ Tris-Glycine gels, and then electrophoretically transferred to polyvinylidene fluoride membranes. The membranes were blocked with $5 \%$ fat-free milk for $1 \mathrm{~h}$ at room temperature, and the blots were incubated with appropriate primary antibodies [type I collagen (1:2,000; ab34710; Abcam); type III collagen (1:2,000; 
Table II. Primer pairs used for quantitative polymerase chain reaction analysis.

\begin{tabular}{|c|c|c|c|}
\hline Gene & Primer sequence $\left(5^{\prime}-3^{\prime}\right)$ & Annealing temperature $\left({ }^{\circ} \mathrm{C}\right)$ & Product size (bp) \\
\hline \multirow[t]{2}{*}{ Type I collagen } & Forward: GGCGGCCAGGGCTCCGACCC & & \\
\hline & Reverse: AATTCCTGGTCTGGGGCACC & 60 & 319 \\
\hline \multirow[t]{2}{*}{ Type III collagen } & Forward: TGGTGTTGGAGCCGCTGCCA & & \\
\hline & Reverse: CTCAGCACTAGAATCTGTCC & 60 & 346 \\
\hline \multirow[t]{2}{*}{ Fibronectin } & Forward: GCCACTGGAGTCTTTACCACA & & \\
\hline & Reverse: CCTCGGTGTTGTAAGGTGGA & 58 & 61 \\
\hline \multirow[t]{2}{*}{$\alpha-S M A$} & Forward: CATCATGCGTCTGGATCTGG & & \\
\hline & Reverse: GGACAATCTCACGCTCAGCA & 60 & 107 \\
\hline \multirow[t]{2}{*}{$C T G F$} & Forward: ACAAGGGCCTCTTCTGTGACTT & & \\
\hline & Reverse: GGTACACCGTACCACCGAAGAT & 60 & 102 \\
\hline \multirow[t]{2}{*}{$I F N-\gamma$} & Forward: TGCAGGTCATTCAGATGTAGCGGA & & \\
\hline & Reverse: TGTCTTCCTTGATGGTCTCCACACTC & 60 & 182 \\
\hline \multirow[t]{2}{*}{$T G F-\beta 1$} & Forward: GAAGTGGATCCACGAGCCCAAG & & \\
\hline & Reverse: GCTGCACTTGCAGGAGCGCAC & 60 & 227 \\
\hline \multirow[t]{2}{*}{$T G F-\beta 3$} & Forward: GGTTTTCCGCTTCAATGTGT & & \\
\hline & Reverse: GCTCGATCCTCTGCTCATTC & 60 & 119 \\
\hline \multirow[t]{2}{*}{$V E G F$} & Forward: ACGAAGTGGTGAAGTTCATGGAA & & \\
\hline & Reverse: AAGATGTCCACCAAGGTCTCGAT & 60 & 73 \\
\hline \multirow[t]{2}{*}{ PAI-1 } & Forward: TCATCATCAATGACTGGGTGAAGAC & & \\
\hline & Reverse: TTCCACTGGCCGTTGAAGTAGAG & 60 & 127 \\
\hline \multirow[t]{2}{*}{ Smad-7 } & Forward: GTGGCATACTGGGAGGAGAA & & \\
\hline & Reverse: GATGGAGAAACCAGGGAACA & 60 & 309 \\
\hline \multirow[t]{2}{*}{$M M P-1$} & Forward: GGAGCTGTAGATGTCCTTGGGGT & & \\
\hline & Reverse: GCCACAACTGCCAAATGGGCTT & 60 & 139 \\
\hline \multirow[t]{2}{*}{$M M P-3$} & Forward: AGGACAAAGCAGGATCACAGTTG & & \\
\hline & Reverse: CCTGGTACCCACGGAACCT & 58 & 68 \\
\hline \multirow[t]{2}{*}{$\underline{G A P D H}$} & Forward: TCACCATCTTCCAGGAGCG & & \\
\hline & Reverse: CTGCTTCACCACCTTCTTGA & 60 & 572 \\
\hline
\end{tabular}

$\alpha$-SMA, $\alpha$-smooth muscle actin; $C T G F$, connective tissue growth factor; $I F N-\gamma$, interferon- $\gamma ; M M P$, matrix metalloproteinase; $P A I-1$, plasminogen activator inhibitor- $1 ; T G F-\beta$, transforming growth factor- $\beta$.

ab7778; Abcam); fibronectin (1:2,000; ab32419; Abcam); p-Smad3 (1:1,000; 8828; Cell Signaling Technology, Inc.); Smad2/3 (1:1,000; 8685; Cell Signaling Technology, Inc.); Smad7 (1:2,000; ab190987; Abcam); p-ERK1/2 (1:1,000; 4370; Cell Signaling Technology, Inc.); ERK1/2 (1:1,000; 4695; Cell Signaling Technology, Inc.)] overnight at $4^{\circ} \mathrm{C}$. The membranes were then incubated with horseradish peroxidase-linked secondary antibodies (Beyotime) for $1 \mathrm{~h}$ at room temperature. The goat anti-rabbit secondary antibodies were purchased from Beyotime (cat. no. A0208) with a dilution of 1:1,000 for $1 \mathrm{~h}$ at room temperature. The blots were visualized using a Super-GL enhanced chemiluminescence reagent (Novland, Shanghai, China) and were exposed onto KODAK X-Omat BT Film (Kodak, Rochester, NY, USA). The results were analyzed using a digital imaging system equipped with AlphaEaseFC software V (Alpha Imager 2000; ProteinSimple, San Jose, CA, USA).
Cell invasion assay. Transwell invasion chambers (membrane pore size, $8 \mu \mathrm{m}$ ) coated with Matrigel (BD Biosciences) were placed into 24 -well plates. Following an overnight culture in serum-free medium, KFs $\left(1 \times 10^{5}\right.$ cells/well) were added to the upper chambers and were incubated with or without various $\mathrm{Rg} 3$ concentrations (50 or $100 \mu \mathrm{g} / \mathrm{ml}$ ) for 24 and $48 \mathrm{~h}$. Normal medium containing serum was placed into the lower chambers. After 24 or $48 \mathrm{~h}$, cells that remained on the upper surface of the membrane were completely removed using a cotton swab. Cells that crossed the Matrigel and migrated to the lower side of the Transwell insert were fixed with $4 \%$ paraformaldehyde for $5 \mathrm{~min}$ at room temperature and stained with DAPI. The number of cells that invaded across the membrane was counted in five random fields under an Olympus CX40 fluorescence microscope (Olympus Corporation).

Immunohistochemical analysis of types I and III collagen, cluster of differentiation (CD)31 and CD34 in keloid explant 


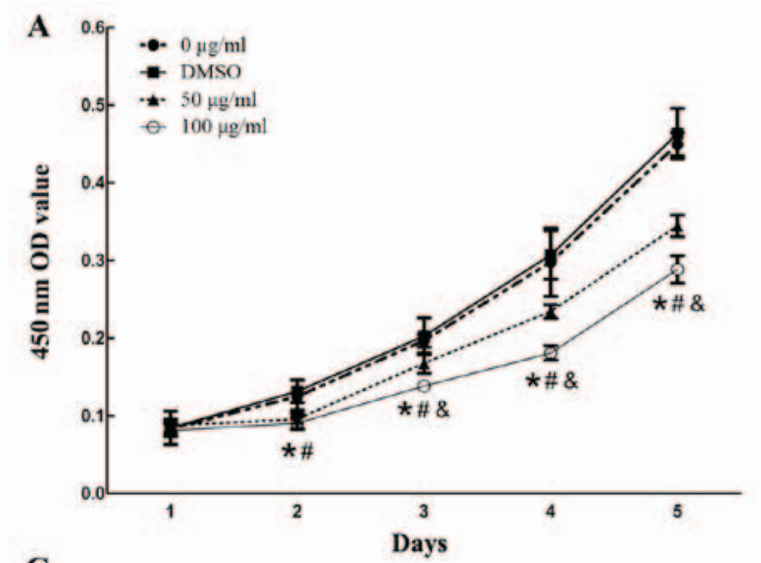

c

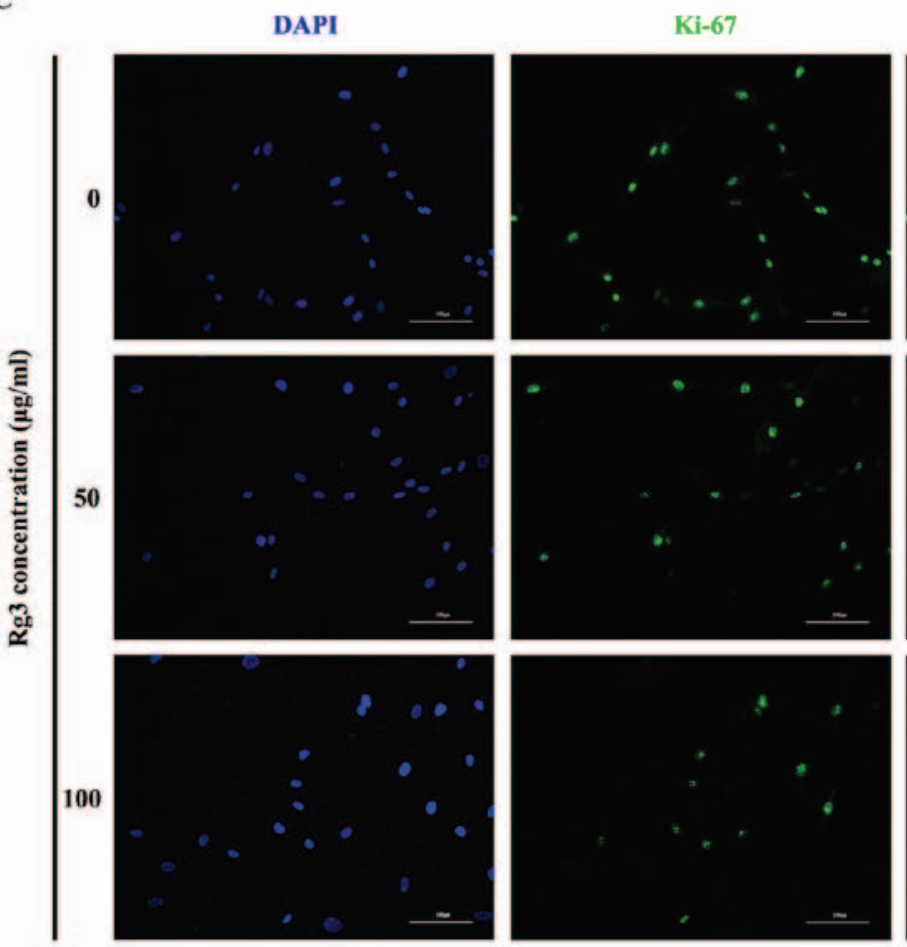

D

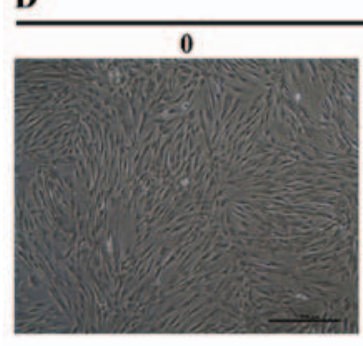

Rg3 concentration $(\mu \mathrm{g} / \mathrm{ml})$

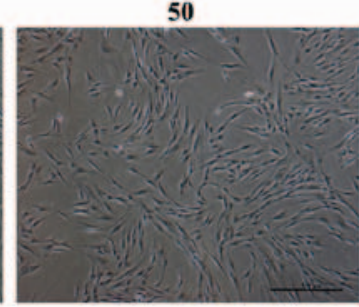

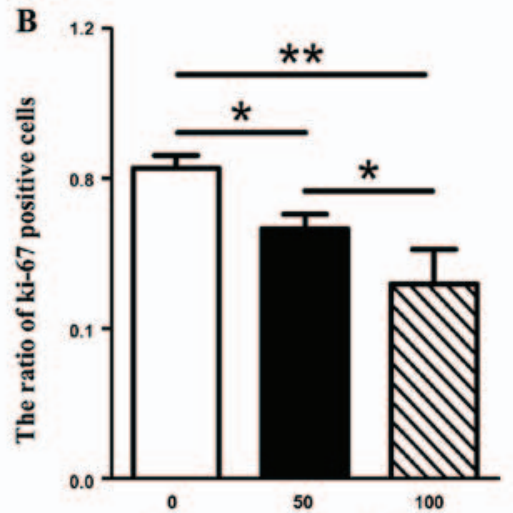

Rg3 concentration $(\mu \mathrm{g} / \mathrm{ml})$

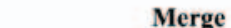

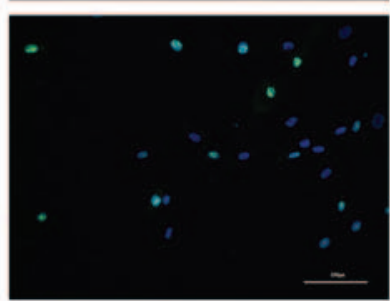
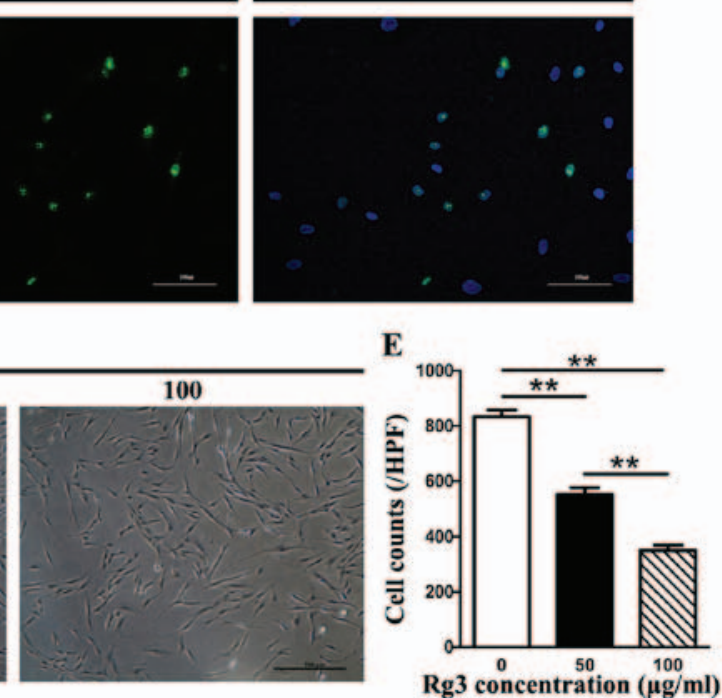

Figure 1. Effects of Rg3 on cell proliferation. (A) Cell proliferation curves of KFs treated with or without various $\mathrm{Rg} 3$ concentrations (50 or $100 \mu \mathrm{g} / \mathrm{ml})$, as determined by Cell Counting kit-8. Both Rg3-treated groups exhibited inhibited cell proliferation from day 2 compared with in the control group ("P<0.05). A statistical difference was detected between the two treated groups from day $3\left({ }^{(} \mathrm{P}<0.05\right)$. A statistical difference existed between the DMSO and Rg3-treated groups $\left({ }^{\prime \prime} \mathrm{P}<0.05\right)$. (B and C) Expression of the proliferation marker Ki-67 was markedly decreased in Rg3-treated groups, as fewer KFs exhibited Ki-67-positive expression compared with in the control group. " $\mathrm{P}<0.05$ and ${ }^{* *} \mathrm{P}<0.01$. Data are expressed as the means \pm standard deviation of triplicate experiments (scale bar, $100 \mu \mathrm{m}$ ). (D and E) Cell morphology of KFs treated with various Rg3 concentrations ( 50 or $100 \mu \mathrm{g} / \mathrm{ml}$ ) for $72 \mathrm{~h}$. Density of KFs was gradually decreased as the concentrations of Rg3 increased. ${ }^{* *} \mathrm{P}<0.01$. Experiments were performed in triplicate. DMSO, dimethyl sulfoxide; OD, optical density; KFs, keloid fibroblasts; Rg3, ginsenoside Rg3 (scale bar, $100 \mu \mathrm{m}$ ).

cultures. Keloid tissues removed from the patients were cut into $1-\mathrm{mm}(1 \times 2 \times 5 \mathrm{~mm})$ tissue explants. Once the tissue sections adhered to the bottom of the dish, medium with or without various $\operatorname{Rg} 3$ concentrations $(50$ or $100 \mu \mathrm{g} / \mathrm{ml}$ ) was added to the wells. Explants were added to $3.5-\mathrm{cm}$ culture dishes. After 6 days, the tissue blocks were fixed with $4 \%$ paraformaldehyde for $24 \mathrm{~h}$ at $4^{\circ} \mathrm{C}$ and were embedded in paraffin. Immunohistochemical staining was performed using a peroxidase-labeled streptavidin-biotin technique. Briefly, tissues embedded in paraffin were cut into $4-\mu \mathrm{m}$ sections and 
A
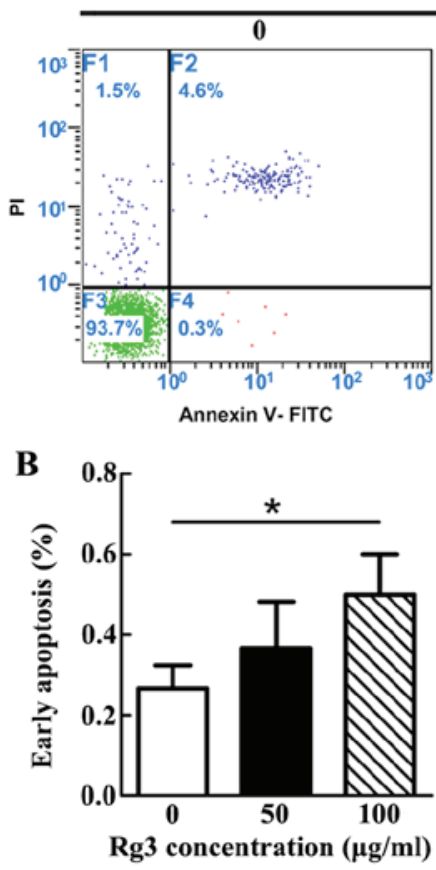

Rg3 concentration $(\mu \mathrm{g} / \mathrm{ml})$
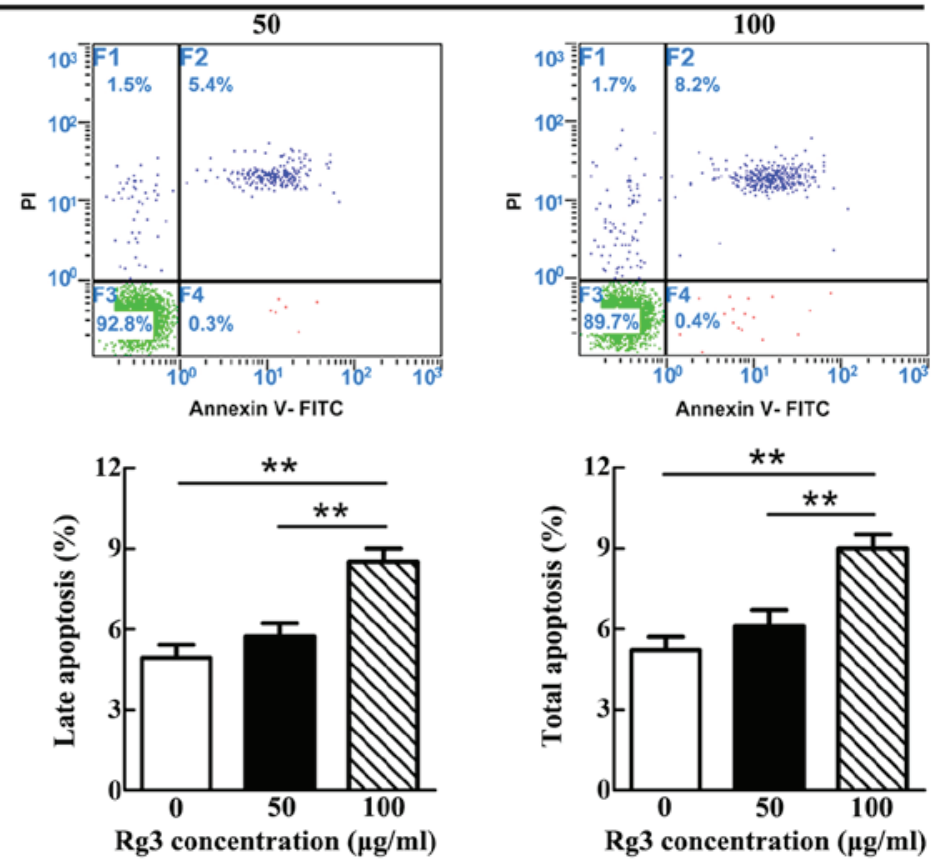

Figure 2. Percentage of apoptotic cells, as measured by FCM after Annexin V/PI staining. (A) Apoptotic rate gradually increased as the concentration of Rg3 increased. (B) Statistical analysis of FCM. Marked differences existed between the control and $100 \mu \mathrm{g} / \mathrm{ml}$-Rg3-treated groups, with regards to early apoptosis, but no distinct differences were detected between the control and $50 \mu \mathrm{g} / \mathrm{ml}-\mathrm{Rg} 3$-treated groups in each phase of apoptosis. ${ }^{*} \mathrm{P}<0.05$. FCM, flow cytometry; FITC, fluorescein isothiocyanate; PI, propidium iodide; $\operatorname{Rg} 3$, ginsenoside $\operatorname{Rg} 3{ }^{* *} \mathrm{P}<0.01$.

placed onto glass slides. After antigen retrieval, the sections were incubated overnight at $4^{\circ} \mathrm{C}$ with primary antibodies. Subsequently, each section was incubated with an appropriate secondary antibody and then detected by the formation of a streptavidin-biotin-horseradish peroxidase complex (Zhongshan-Jinqiao, Beijing, China). Immunostaining was considered positive when the cells were stained brown after the addition of 3\% 3,3'-diaminobenzidine reagent. Sections stained by isotype-matched $\mathrm{IgG}$ instead of primary antibody were used as negative controls. Goat anti-rabbit antibody (SPN-9001) was purchased from Zhongshan-Jinqiao. Paraffin-embedded sections were used for histological staining. Slides were then incubated overnight at $4^{\circ} \mathrm{C}$ with primary antibodies against human type I collagen (1:200; ab34710), type III collagen (1:200; ab7778), CD31 (1:100; ab28364) and CD34 (1:100; ab81289) (Abcam). Subsequently, each section was incubated with the appropriate secondary antibody (Zhongshan-Jinqiao) and with DAB. All the tissue sections were observed under a microscope (Nikon Corporation) at a x400 magnification and images of five random views were captured for each group. The relative density of collagen was analyzed using Image Pro Plus 6.0 software. The number of microvessels was counted in five random fields under a microscope (Olympus Corporation).

Statistical analysis. All assays were performed in triplicate and all results are presented as the means \pm standard deviation. The differences among the three groups were measured using one-way analysis of variance and differences between two groups were determined using Turkey's post-hoc statistical method. SPSS 21.0 software (IBM Corp., Armonk, NY, USA) was used for statistical analysis. $\mathrm{P}<0.05$ was considered to indicate a statistically significant difference.

\section{Results}

Rg3 suppresses KF proliferation. Since excessive and abnormal proliferation of fibroblasts has been reported in keloids, the present study investigated the regulatory function of $\operatorname{Rg} 3$ on the proliferation of KFs using a cell viability assay (CCK-8 assay). In the $\mathrm{Rg} 3$-treated groups, cell proliferation was inhibited from the second day (after $48 \mathrm{~h}$ of drug incubation) compared with in the control group (Fig. 1A). There were significant differences between the Rg3-treated groups and the $0 \mu \mathrm{g} / \mathrm{ml}-\mathrm{Rg} 3$-treated group $(\mathrm{P}<0.05)$. In addition, an apparent difference in cell proliferation between the 50 and $100 \mu \mathrm{g} / \mathrm{ml} \mathrm{Rg} 3$-treated groups was detected from the third day (after $72 \mathrm{~h}$ of drug incubation, $\mathrm{P}<0.05)$. There was also a marked difference detected between the DMSO and Rg3-treated groups $(\mathrm{P}<0.05)$; however, no obvious difference was observed between the $0 \mu \mathrm{g} / \mathrm{ml}-\mathrm{Rg} 3$-treated and DMSO groups. No statistical differences were detected in cell proliferation rate among the groups on day 1 . The present study also investigated the suppressive effects of $\mathrm{Rg} 3$ towards fibroblast growth using Ki-67 immunofluorescence in combination with DAPI nuclear staining (Fig. 1B and C). The expression of the proliferation marker Ki-67 was markedly decreased in Rg3-treated groups, as fewer Ki-67-positive KFs were detected compared with in the control group (Fig. 1C). The ratio of Ki-67-positive cells was significantly different between the untreated and $\mathrm{Rg} 3$-treated groups $(\mathrm{P}<0.05$; Fig. 1B). The effects of various concentrations of Rg3 (50 or $100 \mu \mathrm{g} / \mathrm{ml}$ ) on KF morphology were investigated by microscopy after $72 \mathrm{~h}$. KF density was gradually decreased as the concentrations of $\operatorname{Rg} 3$ increased $(P<0.01$; Fig. $1 D$ and $E)$. These results indicated that KF proliferation was effectively inhibited by certain concentrations of $\mathrm{Rg} 3$. 
A
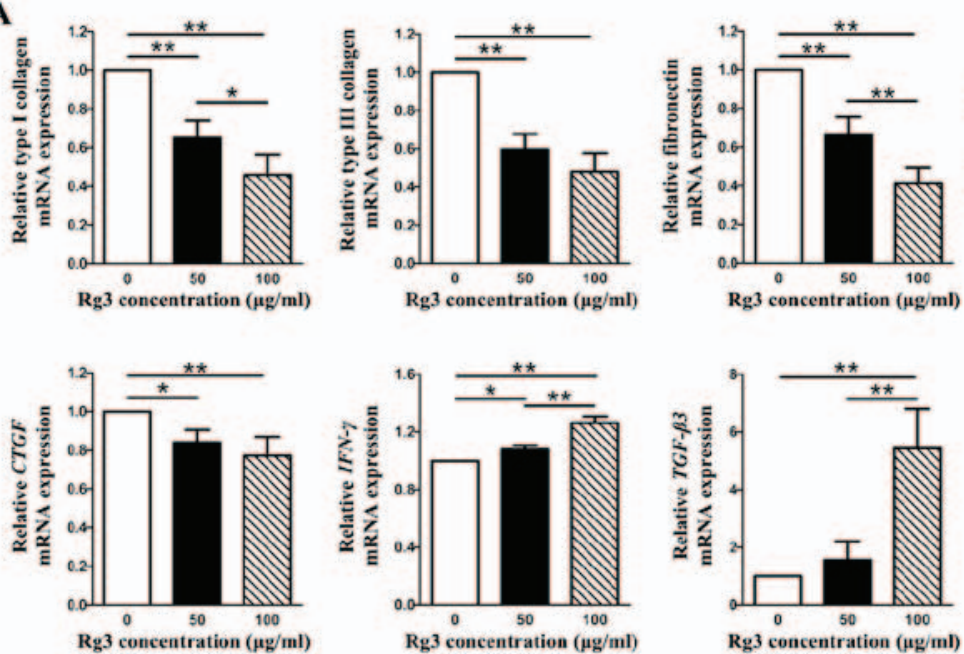

Rg3 concentration $(\mu \mathrm{g} / \mathrm{ml})$
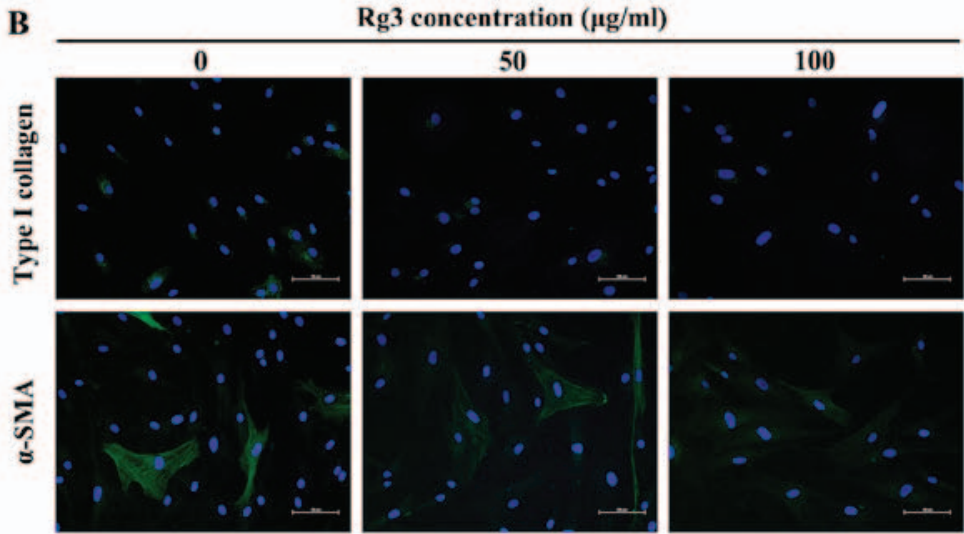

Rg3 concentration $(\mu \mathrm{g} / \mathrm{ml})$

D

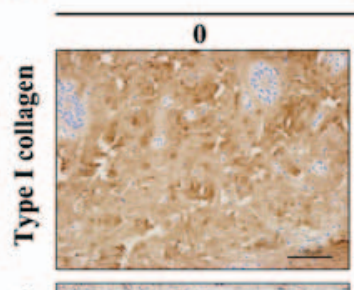

$\mathbf{5 0}$

100
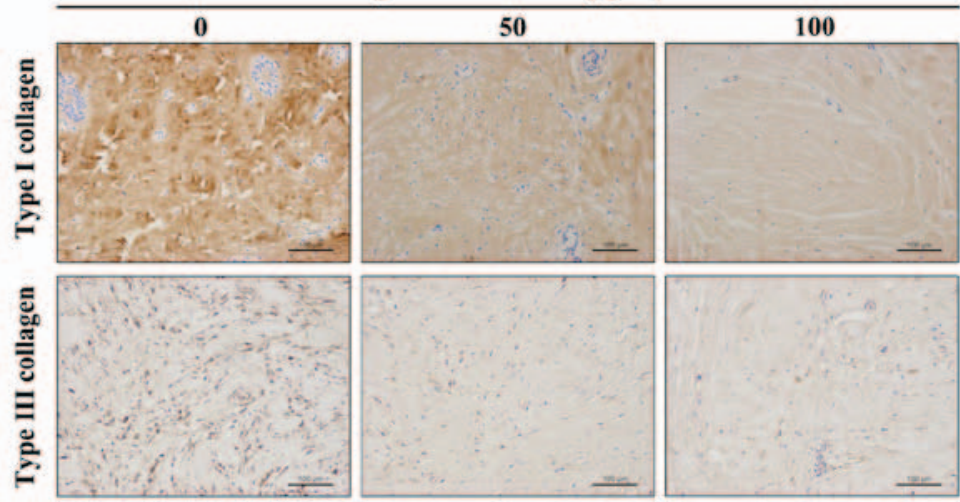

C

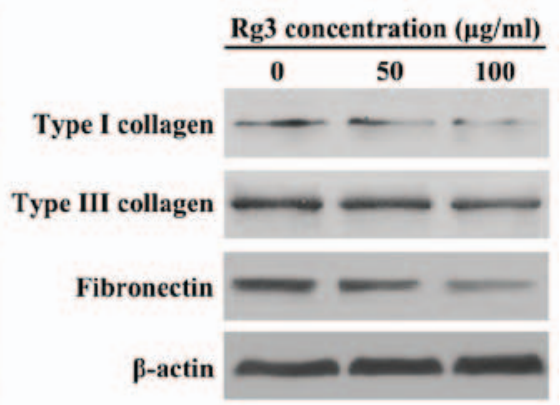

E
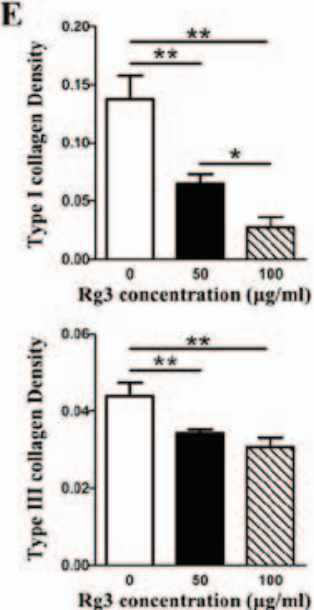

Figure 3. Fibrosis-associated gene and protein expression in KFs treated with or without various Rg3 concentrations (50 or $100 \mu \mathrm{g} / \mathrm{ml})$. (A) Quantitative polymerase chain reaction results of fibrosis-associated genes. The expression levels of types I and III collagen, fibronectin, $\alpha$-SMA and CTGF were markedly decreased in the Rg3-treated groups; however, the expression levels of $I F N-\gamma$ and $T G F-\beta 3$ were increased. ${ }^{*} \mathrm{P}<0.05$ and ${ }^{* *} \mathrm{P}<0.01$. (B) Immunofluorescence analysis of type I collagen and $\alpha$-SMA. The expression of type I collagen and $\alpha$-SMA was visibly weak in the Rg3-treated groups (scale bar, $100 \mu \mathrm{m}$ ). Green is staining $\alpha$-SMA and type I collagen staining; blue staining is nuclear staining. (C) Western blot analysis of types I and III collagen, and fibronectin. Protein expression levels decreased in KFs as the Rg3 concentration increased. (D and E) Immunohistochemical analysis of types I and III collagen in keloid explant cultures. Rg3 suppressed types I and III collagen synthesis compared with in the control group. ${ }^{*} \mathrm{P}<0.05$ and ${ }^{* *} \mathrm{P}<0.01$ (scale bar, $100 \mu \mathrm{m}$ ). $\alpha$-SMA, $\alpha$-smooth muscle actin; $C T G F$, connective tissue growth factor; IFN- $\gamma$, interferon- $\gamma$; KFs, keloid fibroblasts; $\operatorname{Rg} 3$, ginsenoside $\operatorname{Rg} 3 ; T G F-\beta 3$, transforming growth factor- $\beta 3$.

High concentration of Rg3 induces KF apoptosis. The apoptotic rate was gradually increased as the concentration of Rg3 increased (Fig. 2A). However, statistical analysis demonstrated that a significant difference only existed between the control and $100 \mu \mathrm{g} / \mathrm{ml}-\mathrm{Rg} 3$-treated groups, with regards to early apoptosis $(\mathrm{P}<0.05$; Fig. $2 \mathrm{~B})$. With regards to late and total apoptosis, significant differences existed not only between the control and $100 \mu \mathrm{g} / \mathrm{ml}-\mathrm{Rg} 3$-treated groups $(\mathrm{P}<0.01)$, 


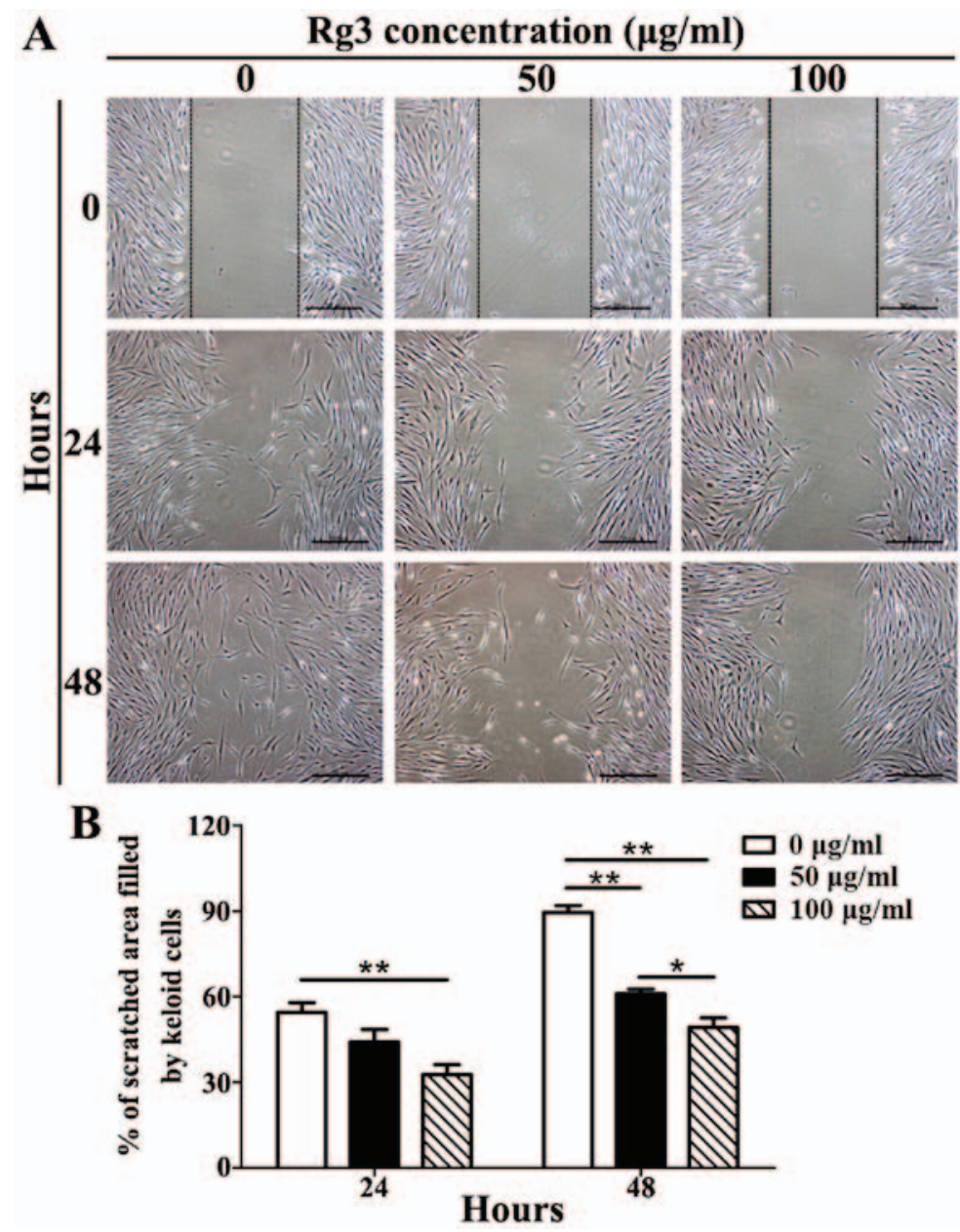

Figure 4. Results of scratch wound assay in KFs treated with or without various Rg3 concentrations (50 or $100 \mu \mathrm{g} / \mathrm{ml})$. (A) Digital images of each wound were captured immediately $(0 \mathrm{~h})$, and 24 and $48 \mathrm{~h}$ after scratch generation (scale bar, $100 \mu \mathrm{m}$ ). (B) Quantitative analysis of the percentage of the scratched area filled by KFs. A significant difference existed between the $100 \mu \mathrm{g} / \mathrm{ml}-\mathrm{Rg} 3$-treated and control groups after $24 \mathrm{~h}$, and among the three groups after $48 \mathrm{~h}$. $\mathrm{P}<0.05 \mathrm{and}$ ${ }^{* *} \mathrm{P}<0.01$. KFs, keloid fibroblasts; Rg3, ginsenoside $\mathrm{Rg} 3$.

but also between the two Rg3-treated groups. Notably, there was no significant difference between the control and $50 \mu \mathrm{g} / \mathrm{ml}-\mathrm{Rg} 3$-treated groups in each phase of apoptosis. The majority of apoptotic KFs in each group were revealed to be undergoing late apoptosis.

Rg3 reduces collagen production and ECM accumulation. The expression levels of types I and III collagen, fibronectin, $\alpha$-SMA, connective tissue growth factor (CTGF), interferon (IFN) $-\gamma$ and transforming growth factor (TGF)- $\beta 3$ were detected in KFs using qPCR, western blot analysis, immunofluorescence and immunohistochemical analysis (Fig. 3). The mRNA expression levels of types I and III collagen, fibronectin, $\alpha$-SMA and $C T G F$ were significantly decreased in the Rg3-treated groups compared with in the control group $(\mathrm{P}<0.05)$, thus indicating that $\mathrm{Rg} 3$ may exert antifibrogenic effects in KFs (Fig. 3A). In addition, there were marked differences between the $50 \mu \mathrm{g} / \mathrm{ml}$ and $100 \mu \mathrm{g} / \mathrm{ml}-\mathrm{Rg} 3$-treated groups $(\mathrm{P}<0.05)$ with regards to the mRNA expression levels of type I collagen, fibronectin and $\alpha$-SMA; however, no significant difference was detected between these groups with regards to type III collagen and CTGF. Furthermore, the mRNA expression levels of $I F N-\gamma$ and $T G F-\beta 3$ were significantly increased in the $\mathrm{Rg} 3$-treated groups compared with in the control group
$(\mathrm{P}<0.05)$, thus indicating that $\mathrm{Rg} 3$ may strengthen antifibrotic effects in KFs (Fig. 3A). Intracellular localization of type I collagen and $\alpha$-SMA was examined by immunofluorescence microscopy using the corresponding antibodies. The expression of type I collagen and $\alpha$-SMA was visibly weak in the Rg3-treated groups; the most obvious effects were detected in the $100 \mu \mathrm{g} / \mathrm{ml}-\mathrm{Rg} 3$-treated group (Fig. 3B). Western blot analysis indicated that types I and III collagen, and fibronectin protein expression levels were decreased in KFs as the concentration of Rg3 increased (Fig. 3C). This tendency was particularly obvious with regards to type I collagen and fibronectin. The immunohistochemical analysis of types I and III collagen in keloid explant cultures indicated that $\mathrm{Rg} 3$ suppressed types I and III collagen synthesis compared with in the control group (Fig. 3D). In addition, a marked difference was detected among the three groups with regards to the relative density of collagen $\mathrm{I}(\mathrm{P}<0.05$; Fig. 3E). With regards to type III collagen, a statistical difference existed between the untreated group and the treated groups, but not between the two treated groups (Fig. 3E). These results suggested that $\operatorname{Rg} 3$ may downregulate the expression of profibrotic genes and proteins (types I and III collagen, fibronectin, $\alpha$-SMA and CTGF) and upregulate the expression of antifibrotic genes $(I F N-\gamma$ and $T G F-\beta 3)$ in KFs. 

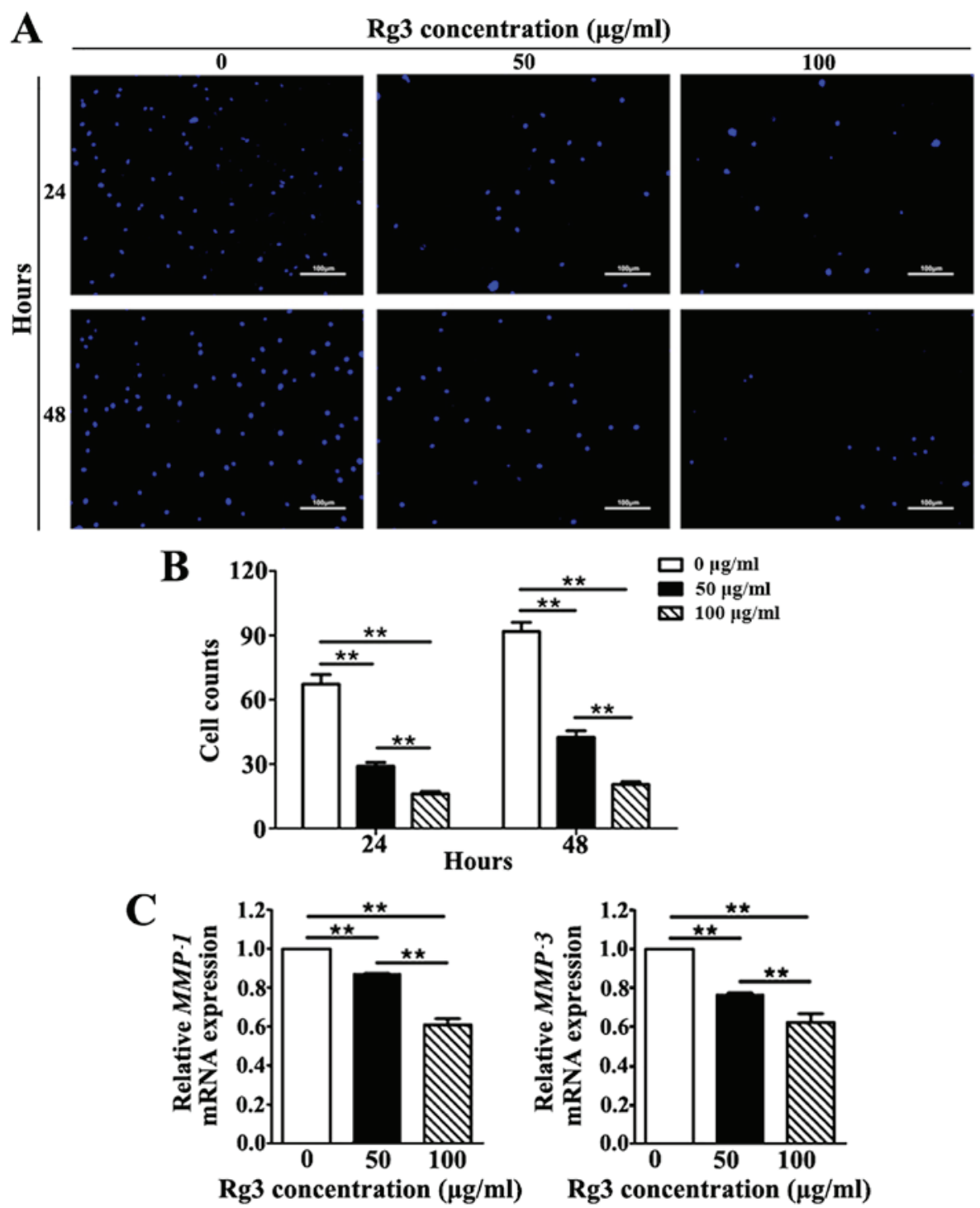

Figure 5. Invasive capabilities of KFs were investigated by Transwell invasion assay. (A and B) Images of the invasive cells were captured and counted under a fluorescence microscope. In the Rg3-treated groups, less KFs migrated across the Matrigel-coated polycarbonate membrane to the lower chambers at 24 and $48 \mathrm{~h}$ (scale bar, $100 \mu \mathrm{m}$ ). ${ }^{* *} \mathrm{P}<0.01$. (C) Quantitative polymerase chain reaction analysis of $M M P-1$ and $M M P-3$. The mRNA expression levels were markedly downregulated in $\mathrm{Rg} 3$-treated groups. ${ }^{* *} \mathrm{P}<0.01$. KFs, keloid fibroblasts; $M M P$, matrix metalloproteinase; $\operatorname{Rg} 3$, ginsenoside $\operatorname{Rg} 3$.

Rg3 inhibits cell migration. The results of a scratch wound assay indicated that $\operatorname{Rg} 3$ was able to markedly inhibit KF migration (Fig. 4A). After $24 \mathrm{~h}, \mathrm{KFs}$ in the control group had migrated $55.43 \pm 6.03 \%$ (mean \pm standard deviation) of the scratched area, whereas $50 \mu \mathrm{g} / \mathrm{ml}$-treated KFs had migrated $44.08 \pm 7.66 \%$ and $100 \mu \mathrm{g} / \mathrm{ml}$-treated KFs had migrated only $32.60 \pm 6.13 \%$. There were significant differences between the $100 \mu \mathrm{g} / \mathrm{ml}-\mathrm{Rg} 3$-treated and control groups $(\mathrm{P}<0.01)$, but not between the $50 \mu \mathrm{g} / \mathrm{ml}-\mathrm{Rg} 3$-treated and control groups (Fig. 4B). After $48 \mathrm{~h}$, KFs in the control group had migrated $89.46 \pm 4.12 \%$ of the scratched area, whereas $50 \mu \mathrm{g} / \mathrm{ml}$-treated KFs had migrated $60.96 \pm 2.85 \%$ and $100 \mu \mathrm{g} / \mathrm{ml}$-treated KFs had migrated only $49.15 \pm 5.79 \%$. Significant differences were detected among the three groups $(\mathrm{P}<0.05$; Fig. 4B). These results indicated that $\mathrm{Rg} 3$ may markedly suppress the migration of KFs.

Rg3 suppresses KF invasion. The invasive capability of KFs was investigated using a Transwell invasion assay. The number of KFs that migrated across the Matrigel-coated polycarbonate membrane to the lower chambers was markedly increased in the untreated group compared with in the $\mathrm{Rg} 3$-treated groups at 24 and $48 \mathrm{~h}$ (Fig. 5A). Rg3 diminished the invasive capability of KFs by reducing the number of cells that migrated across the Matrigel-coated membrane in a concentration-dependent manner; a significant difference was detected among the three groups at both time-points $(\mathrm{P}<0.01$; Fig. 5B). Furthermore, to validate the inhibitory effects of $\mathrm{Rg} 3$ towards the invasive capability of KFs, the mRNA expression levels of matrix metalloproteinase (MMP)- 1 and $M M P-3$, which serve a pivotal role in cell invasion during wound healing and cancer metastasis, were detected (20). The results indicated that the mRNA expression levels of $M M P-1$ and $M M P-3$ were significantly downregulated in $\mathrm{Rg} 3$-treated groups $(\mathrm{P}<0.01$; Fig. 5C). These results revealed that $\mathrm{Rg} 3$ may suppress the invasive capability of KFs.

GS-Rg3 suppresses angiogenesis in keloid explant cultures. The number of CD31 and CD34 positively stained 


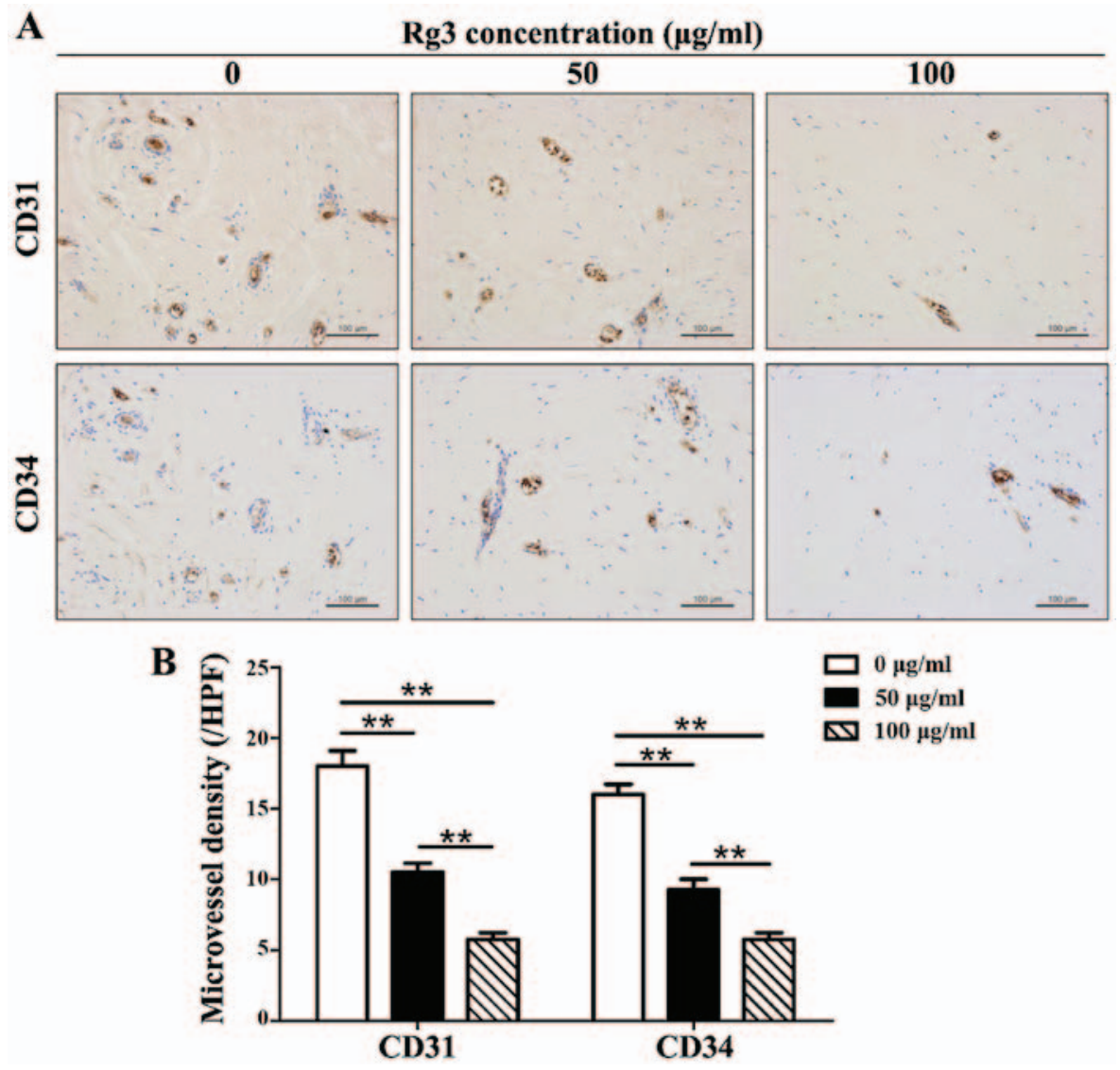

Figure 6. Immunohistochemical analysis of CD31 and CD34 in keloid explant cultures. (A) Number of CD31 and CD34 positively stained microvessels was decreased in Rg3-treated groups (scale bar, $100 \mu \mathrm{m}$ ). (B) Quantitative analysis of immunohistochemistry indicated that microvessel density was reduced by $\sim 1 / 2$ in the $50 \mu \mathrm{g} / \mathrm{ml}$-treated group and by $\sim 2 / 3$ in the $100 \mu \mathrm{g} / \mathrm{ml}$-treated group compared with in the control group. ${ }^{* *} \mathrm{P}<0.01$. CD, cluster of differentiation; Rg3, ginsenoside Rg3.

microvessels was decreased in Rg3-treated groups (Fig. 6A). The results indicated that microvessel density was reduced by $\sim 1 / 2$ in the $50 \mu \mathrm{g} / \mathrm{ml}$-treated group and by $\sim 2 / 3$ in the $100 \mu \mathrm{g} / \mathrm{ml}$-treated group compared with in the control group (Fig. 6B). Significant differences existed among the three groups $(\mathrm{P}<0.01)$ with regards to $\mathrm{CD} 31^{+}$and $\mathrm{CD} 34^{+}$ microvessels.

Rg3 inhibits the biological behavior of KFs through TGF- $\beta /$ Smad and ERK pathways. The mRNA expression levels of $T G F-\beta 1$, which has been reported to be highly expressed in KFs (21), $V E G F$, which is associated with malignant diseases (22), and plasminogen activator inhibitor-1 (PAI-1), which is strongly increased by $T G F-\beta 1$, were significantly decreased in the Rg3-treated groups compared with in the control group $(\mathrm{P}<0.05$; Fig. 7A). Whereas, the mRNA expression levels of Smad7, which is a negative feedback regulator in the TGF- $\beta 1 /$ Smad pathway, was markedly increased in response to $\operatorname{Rg} 3$ compared with in the control group $(\mathrm{P}<0.01)$, thus indicating that TGF- $\beta 1$-induced decreases in Smad7 expression were reversed by $\mathrm{Rg} 3$ in a concentration-dependent manner (Fig. 7A). Statistical analysis indicated that there were significant differences in the expression levels of all genes among the three groups $(\mathrm{P}<0.05)$. The protein expression levels of p-Smad 2 and p-Smad3, which are enhanced by TGF- $\beta 1$, were markedly decreased in $\mathrm{Rg} 3$-treated KFs (Fig. 7B). In addition, p-ERK1/2 expression was suppressed by Rg3 treat- ment in KFs (Fig. 7B). However, the protein expression levels of Smad7 were increased in the Rg3-treated groups compared with in the control group, which was similar to the findings of the qPCR analysis (Fig. 7A). The protein expression levels of total Smad2/3 and total ERK1/2 remained almost unchanged in the three groups.

\section{Discussion}

$\operatorname{Rg} 3$ has been acknowledged as a biologically active component of Panax ginseng. In a previous study, the effects of $\mathrm{Rg} 3$ on tumor inhibition were thoroughly investigated (23). Keloids are regarded as benign tumors, but behave in part like malignant tumors, due to their abilities to extend beyond the original wound margins and invade into adjacent tissues. A single effective therapy for keloids is not yet available. The present study is the first, to the best of our knowledge, to indicate that Rg3 exerts effective therapeutic outcomes in the field of keloid treatment. The results of the present study demonstrated that $\mathrm{Rg} 3$ could inhibit the proliferation, angiogenesis and collagen synthesis of KFs in vitro via the TGF- $\beta /$ Smad and ERK signaling pathways.

The present results suggested that $\mathrm{Rg} 3$ exerts marked antiproliferative effects on KFs. This was verified by the decreased expression of the proliferative marker Ki-67, which was detected in Rg3-treated KFs in a concentration-dependent manner. In addition, the results of the cell proliferation assay 
A
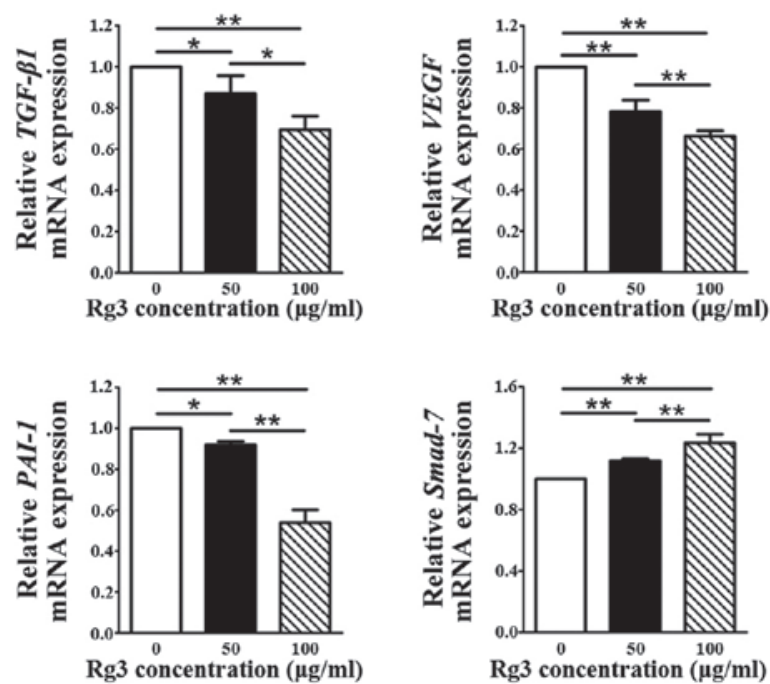

B

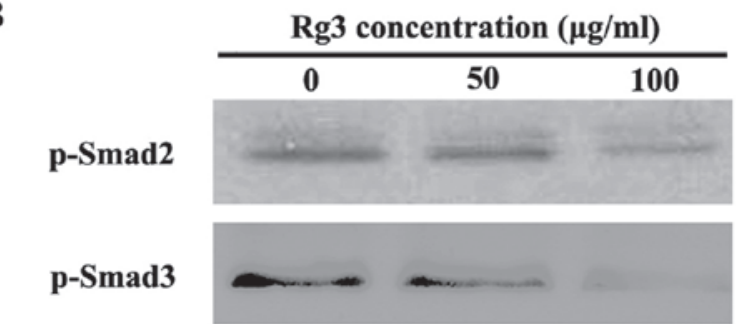

T-Smad2/3

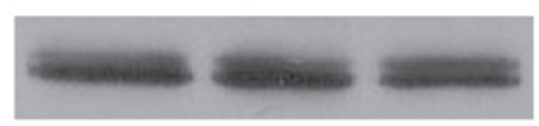

p-ERK1/2

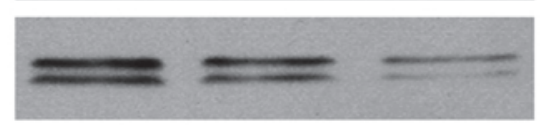

T-ERK1/2

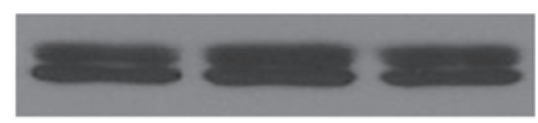

$\beta$-actin

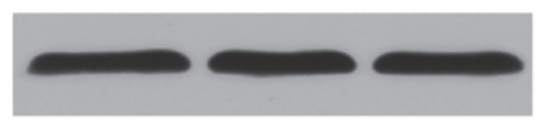

Smad7

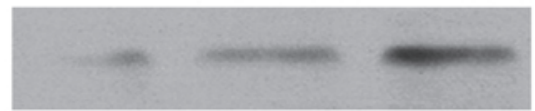

$\beta$-actin

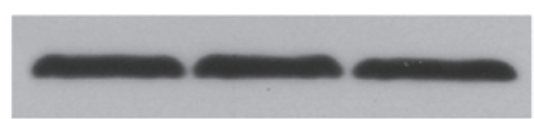

Figure 7. Expression of genes and proteins associated with the signaling pathways underlying the effects of $\operatorname{Rg} 3$ on KFs. (A) Quantitative polymerase chain reaction analysis of TGF- $\beta 1 /$ Smad-associated and vascularization-associated molecules. mRNA levels of $T G F-\beta 1, V E G F$ and PAI- 1 were decreased in the $\mathrm{Rg} 3$-treated groups; however, the mRNA expression levels of $\operatorname{Smad} 7$ were increased. ${ }^{*} \mathrm{P}<0.05$ and ${ }^{* *} \mathrm{P}<0.01$. (B) Western blot analysis of proteins in the TGF- $\beta 1 /$ Smad and ERK signaling pathways. The protein expression levels of p-Smad2, p-Smad3 and p-ERK1/2 were suppressed by Rg3 in KFs, whereas the protein levels of Smad7 were increased in the Rg3-treated groups. ERK, extracellular-signal regulated kinase; KFs, keloid fibroblasts; p-, phosphorylated; PAI-1, plasminogen activator inhibitor-1; Rg3, ginsenoside Rg3; t-, total; $T G F-\beta 1$, transforming growth factor- $\beta 3 ; V E G F$, vascular endothelial growth factor.

indicated that $\operatorname{Rg} 3$ exerted inhibitory effects after $48 \mathrm{~h}$, thus suggesting that $\mathrm{Rg} 3$ could effectively suppress the growth of keloids. The FCM analysis demonstrated that treatment with a relatively low concentration of $\operatorname{Rg} 3$ could not obviously elevate the rate of apoptosis, whereas a high Rg3 concentration could markedly increase the percentage of cells undergoing apoptosis. These results indicated that the relatively low concentration of $\mathrm{Rg} 3$ was able to markedly inhibit KF proliferation, whereas the high concentration of Rg3 not only inhibited cell proliferation but also induced cell apoptosis.

The abnormal reaction of fibroblasts is a pivotal factor in the process of keloid formation. Therefore, excessive collagen and aberrant ECM deposition, potentially caused by increased proliferation of fibroblasts, are distinct features in keloids (24). In the process of keloid formation, numerous profibrogenic molecules serve important functions. In the dermis of keloids, type I collagen, elastin and fibronectin all exhibit increased levels (25). In the process of wound repair, the appropriate appearance and subsequent disappearance of myofibroblasts is important, and ensures normal healing. Myofibroblasts are characterized by $\alpha$-SMA expression. In response to the aberrant accumulation of ECM components, myofibroblasts do not disappear as usual and persistently express $\alpha$-SMA (26). Therefore, $\alpha$-SMA is often detected at higher levels in keloids than in normal fibroblasts (27). CTGF is generated by fibroblasts, serves an important role in cell proliferation and is involved in numerous mechanisms, including regulation of the TGF- $\beta 1$ signaling pathway, positive feedback for fibroblast proliferation, epidermal regeneration, and accumulation and rebuilding of the ECM, as well as development of granulation tissue $(28,29)$. Increased levels of CTGF have been detected in keloids compared with in normal skin (30). Compared with the aforementioned profibrogenic molecules, IFN- $\gamma$ and TGF- $\beta 3$ are antifibrogenic molecules, which are associated with the inhibition of proliferation and reduced fibrosis $(31,32)$; they often exhibit low expression levels in keloids. In the present study, the mRNA and protein expression levels of types I and III collagen, fibronectin and $\alpha$-SMA, and the mRNA expression levels of $C T G F$, were decreased following treatment with Rg3, whereas the mRNA expression levels of $I F N-\gamma$ and $T G F-\beta 3$ were elevated, thus indicating that $\operatorname{Rg} 3$ could effectively reduce collagen production and ECM accumulation.

Keloids are regarded as benign tumors; however, they are sometimes identified as malignant tumors, due to their ability to invade surrounding tissues (33). The results of scratch wound and Transwell invasion assays demonstrated that Rg3 was able to reduce KF migratory and invasive capabilities, which are important indicators of keloid progression. The Transwell invasion assay simulates the invasive process and was used to detect the therapeutic effects of Rg3 towards KF invasion in vitro. Furthermore, numerous members of the MMP family are able to degrade the basement membrane, and thus mediate the migratory and invasive activity of KFs (34). It has been reported that MMP-1 and MMP-3 are active in the process of ECM degradation, and are highly expressed in keloids, particularly during the active stage in order to facilitate the invasive action of KFs $(35,36)$. In the present study, the mRNA expression levels of $M M P-1$ and $M M P-3$ were markedly decreased in the $\mathrm{Rg} 3$-treated groups, thus indicating that $\mathrm{Rg} 3$ may suppress the migration and invasion of KFs in keloid disease. 
The key role that the TGF- $\beta$ signaling pathway serves in the formation of keloids has been reported in numerous studies $(37,38)$. The TGF- $\beta$ family is involved in numerous physiological activities, including cell proliferation, migration, differentiation, deposition and ECM remodeling, as well as the modulation of other signaling pathways. It is well accepted that TGF- $\beta 1$ transmits signals via the Smad family (e.g. p-Smad2/Smad3) inside the cell. Smad family members then relay signals in turn and finally act on target genes, particularly fibrosis-associated genes (39). However, Smad7 serves as a negative feedback regulator that is able to obstruct p-Smad2 and -Smad3, and their polymer with Smad4 (40). Therefore, the present study detected the expression of crucial molecules or proteins in the TGF- $\beta /$ Smad pathway, in order to determine the underlying mechanisms of the effects of $\mathrm{Rg} 3$ on keloids. The present study demonstrated that $\mathrm{Rg} 3$ markedly reduced the mRNA expression levels of $T G F-\beta 1$, the protein expression levels of $\mathrm{p}-\mathrm{Smad} 2$ and $\mathrm{p}-\mathrm{Smad} 3$, and increased Smad7 at both the mRNA and protein levels.

VEGF is a critical factor that is predominantly involved in angiogenesis, inflammatory response and granulation tissue formation. The expression levels of VEGF are higher in keloid tissues and fibroblasts compared with in associated normal skin (41). Angiogenesis is essential for tumor growth; therefore, VEGF is pivotal for keloid and malignant tumor progression. After combining to its specific receptors (VEGFR-1 or VEGFR-2), VEGF activates the ERK1/2 signaling pathway in KFs (42). The present study demonstrated that $\operatorname{Rg} 3$ could markedly reduce the mRNA expression levels of $V E G F$ and the protein expression levels of p-ERK1/2. Furthermore, previous studies have demonstrated that PAI-1 may be upregulated by TGF- $\beta 1$ and VEGF (42-44). PAI-1 has been reported to be intrinsically highly expressed in KFs (44). It has also been suggested that elevated levels of PAI-1 may increase ECM deposition in keloids (42). Consequently, Rg3-induced downregulation of $P A I-1$ detected in the present study may decrease collagen accumulation and suppress keloid formation.

Due to the lack of a keloid animal model, keloid explant culture has been extensively applied in the study of pathophysiological processes. This method results in the maintenance of cellular processes, vasculature and perhaps some interactions, which may not be observed in in vitro assays. In the present study, $\operatorname{Rg} 3$ significantly inhibited collagen synthesis and reduced the quantity of $\mathrm{CD} 31^{+} / \mathrm{CD} 34^{+}$ microvessels within keloid tissue sections, further corroborating the inhibitory and antiangiogenic effects of $\mathrm{Rg} 3$.

In conclusion, the present study clearly demonstrated that Rg3 may inhibit KF proliferation, invasion, angiogenesis and collagen accumulation. In addition, the present study indicated that these effects were involved in the TGF- $\beta / S \operatorname{mad}$ and ERK1/2 signaling pathways. These findings provide information to suggest that $\operatorname{Rg} 3$ may be considered a potential therapeutic agent used to suppress keloid formation. However, in vivo studies and prospective clinical trials are required to further confirm the therapeutic effects of $\mathrm{Rg} 3$.

\section{Acknowledgements}

The authors would like to thank the Shanghai Key Laboratory of Tissue Engineering for technical assistance. The present study was supported in part by the National Natural Science Foundation of China (grant nos. 81372073 and 81772099).

\section{References}

1. Trace AP, Enos CW, Mantel A and Harvey VM: Keloids and Hypertrophic Scars: A Spectrum of Clinical Challenges. Am J Clin Dermatol 17: 201-223, 2016.

2. English RS and Shenefelt PD: Keloids and hypertrophic scars. Dermatol Surg 25: 631-638, 1999.

3. Wang R, Chen J, Zhang Z and Cen Y: Role of chymase in the local renin-angiotensin system in keloids: Inhibition of chymase may be an effective therapeutic approach to treat keloids. Drug Des Devel Ther 9: 4979-4988, 2015.

4. Lu WS, Zheng XD, Yao XH and Zhang LF: Clinical and epidemiological analysis of keloids in Chinese patients. Arch Dermatol Res 307: 109-114, 2015.

5. Butler PD, Longaker MT and Yang GP: Current progress in keloid research and treatment. J Am Coll Surg 206: 731-741, 2008.

6. Bijlard E, Steltenpool S and Niessen FB: Intralesional 5-fluorouracil in keloid treatment: A systematic review. Acta Derm Venereol 95: 778-782, 2015

7. Ud-Din S and Bayat A: Strategic management of keloid disease in ethnic skin: A structured approach supported by the emerging literature. Br J Dermatol 169 (Suppl 3): 71-81, 2013.

8. Liu T, Peng YF, Jia C, Yang BH, Tao X, Li J and Fang X: Ginsenoside $\mathrm{Rg} 3$ improves erectile function in streptozotocin-induced diabetic rats. J Sex Med 12: 611-620, 2015.

9. Yuan HD, Quan HY, Zhang Y, Kim SH and Chung SH: 20(S)-Ginsenoside Rg3-induced apoptosis in HT-29 colon cancer cells is associated with AMPK signaling pathway. Mol Med Rep 3: 825-831, 2010.

10. He BC, Gao JL, Luo X, Luo J, Shen J, Wang L, Zhou Q, Wang YT, Luu HH, Haydon RC, et al: Ginsenoside Rg3 inhibits colorectal tumor growth through the downregulation of Wnt/ $\beta$-catenin signaling. Int J Oncol 38: 437-445, 2011.

11. Wang JH, Nao JF, Zhang M and He P: 20(s)-ginsenoside Rg3 promotes apoptosis in human ovarian cancer HO-8910 cells through PI3K/Akt and XIAP pathways. Tumour Biol 35: 11985-11994, 2014.

12. Joo SS, Yoo YM, Ahn BW, Nam SY, Kim YB, Hwang KW and Lee DI: Prevention of inflammation-mediated neurotoxicity by $\mathrm{Rg} 3$ and its role in microglial activation. Biol Pharm Bull 31: 1392-1396, 2008.

13. Chen QJ, Zhang MZ and Wang LX: Gensenoside Rg3 inhibits hypoxia-induced VEGF expression in human cancer cells. Cell Physiol Biochem 26: 849-858, 2010.

14. Pazyar N, Omidian M and Jamshydian N: Ginseng as a potential novel addition to the antikeloid weaponry. Phytother Res 26: 1579-1580, 2012.

15. Liu JP, Lu D, Nicholson RC, Zhao WJ, Li PY and Wang F: Toxicity of a novel anti-tumor agent 20(S)-ginsenoside Rg3: A 26-week intramuscular repeated administration study in rats. Food Chem Toxicol 50: 3388-3396, 2012.

16. Kim SM, Lee SY, Cho JS, Son SM, Choi SS, Yun YP, Yoo HS, Yoon DY, Oh KW, Han SB, et al: Combination of ginsenoside Rg3 with docetaxel enhances the susceptibility of prostate cancer cells via inhibition of NF-kappaB. Eur J Pharmacol 631: $1-9,2010$.

17. Livak and Schmittgen: Analysis of relative gene expression data using real-time quantitative PCR and the $2-\Delta \Delta \mathrm{Ct}$ method. Methods 25: 402-408, 2001.

18. Lan CC, Liu IH, Fang AH, Wen CH and Wu CS: Hyperglycaemic conditions decrease cultured keratinocyte mobility: Implications for impaired wound healing in patients with diabetes. Br J Dermatol 159: 1103-1115, 2008.

19. Shin JU, Lee WJ, Tran TN, Jung I and Lee JH: Hsp70 knockdown by siRNA decreased collagen production in keloid fibroblasts. Yonsei Med J 56: 1619-1626, 2015.

20. Gill SE and Parks WC: Metalloproteinases and their inhibitors: Regulators of wound healing. Int J Biochem Cell Biol 40: 1334-1347, 2008.

21. Liang CJ, Yen YH, Hung LY, Wang SH, Pu CM, Chien HF, Tsai JS, Lee CW, Yen FL and Chen YL: Thalidomide inhibits fibronectin production in TGF- $\beta 1$-treated normal and keloid fibroblasts via inhibition of the p38/Smad3 pathway. Biochem Pharmacol 85: 1594-1602, 2013. 
22. Schäfer M and Werner S: Cancer as an overhealing wound: An old hypothesis revisited. Nat Rev Mol Cell Biol 9: 628-638, 2008.

23. Shin YM, Jung HJ, Choi WY and Lim CJ: Antioxidative, anti-inflammatory, and matrix metalloproteinase inhibitory activities of 20(S)-ginsenoside Rg3 in cultured mammalian cell lines. Mol Biol Rep 40: 269-279, 2013.

24. Dong X, Mao S and Wen H: Upregulation of proinflammatory genes in skin lesions may be the cause of keloid formation (Review). Biomed Rep 1: 833-836, 2013.

25. Lee WJ, Ahn HM, Roh H, Na Y, Choi IK, Lee JH, Kim YO, Lew DH and Yun CO: Decorin-expressing adenovirus decreases collagen synthesis and upregulates MMP expression in keloid fibroblasts and keloid spheroids. Exp Dermatol 24: 591-597, 2015.

26. Rao K B, Malathi N, Narashiman S and Rajan ST: Evaluation of myofibroblasts by expression of alpha smooth muscle actin: A marker in fibrosis, dysplasia and carcinoma. J Clin Diagn Res 8 : ZC14-ZC17, 2014.

27. Chipev CC, Simman R, Hatch G, Katz AE, Siegel DM and Simon M: Myofibroblast phenotype and apoptosis in keloid and palmar fibroblasts in vitro. Cell Death Differ 7: 166-176, 2000.

28. Mun JH, Kim YM, Kim BS, Kim JH, Kim MB and Ko HC Simvastatin inhibits transforming growth factor- $\beta 1$-induced expression of type I collagen, CTGF, and $\alpha$-SMA in keloid fibroblasts. Wound Repair Regen 22: 125-133, 2014.

29. Zhu R, Yue B, Yang Q, Ma Y, Huang G, Guan M, Avram MM and $\mathrm{Lu} \mathrm{Z}$ : The effect of $595 \mathrm{~nm}$ pulsed dye laser on connective tissue growth factor (CTGF) expression in cultured keloid fibroblasts. Lasers Surg Med 47: 203-209, 2015.

30. Khoo YT, Ong CT, Mukhopadhyay A, Han HC, Do DV, Lim IJ and Phan TT: Upregulation of secretory connective tissue growth factor (CTGF) in keratinocyte-fibroblast coculture contributes to keloid pathogenesis. J Cell Physiol 208: 336-343, 2006.

31. Duncan MR and Berman B: Differential regulation of glycosaminoglycan, fibronectin, and collagenase production in cultured human dermal fibroblasts by interferon-alpha, -beta, and -gamma. Arch Dermatol Res 281: 11-18, 1989.

32. Wu Y, Peng Y, Gao D, Feng C, Yuan X, Li H, Wang Y, Yang L, Huang S and Fu X: Mesenchymal stem cells suppress fibroblast proliferation and reduce skin fibrosis through a TGF- $\beta 3$-dependent activation. Int J Low Extrem Wounds 14: 50-62, 2015 .

33. Yoshimoto H, Ishihara H, Ohtsuru A, Akino K, Murakami R, Kuroda $H$, Namba $H$, Ito $M$, Fujii $T$ and Yamashita $S$ : Overexpression of insulin-like growth factor-1 (IGF-I) receptor and the invasiveness of cultured keloid fibroblasts. Am J Pathol 154: 883-889, 1999.

34. Ma H, Cai H, Zhang Y, Wu J, Liu X, Zuo J, Jiang W, Ji G, Zhang Y, Liu C, et al: Membrane palmitoylated protein 3 promotes hepatocellular carcinoma cell migration and invasion via upregulating matrix metalloproteinase 1. Cancer Lett 344: 74-81, 2014.
35. Fujiwara M, Muragaki Y and Ooshima A: Keloid-derived fibroblasts show increased secretion of factors involved in collagen turnover and depend on matrix metalloproteinase for migration. Br J Dermatol 153: 295-300, 2005.

36. Uchida G, Yoshimura K, Kitano Y, Okazaki M and Harii K: Tretinoin reverses upregulation of matrix metalloproteinase-13 in human keloid-derived fibroblasts. Exp Dermatol 12 (Suppl 2): 35-42, 2003.

37. Lee $\mathrm{CH}$, Hong $\mathrm{CH}$, Chen YT, Chen YC and Shen MR: TGF-betal increases cell rigidity by enhancing expression of smooth muscle actin: Keloid-derived fibroblasts as a model for cellular mechanics. J Dermatol Sci 67: 173-180, 2012.

38. Song R, Li G and Li S: Aspidin PB, a novel natural anti-fibrotic compound, inhibited fibrogenesis in TGF- $\beta 1$-stimulated keloid fibroblasts via PI-3K/Akt and Smad signaling pathways. Chem Biol Interact 238: 66-73, 2015.

39. Branton MH and Kopp JB: TGF- $\beta$ and fibrosis. Microbes Infect 1: 1349-1365, 1999

40. Nakao A, Afrakhte M, Morén A, Nakayama T, Christian JL, Heuchel R, Itoh S, Kawabata M, Heldin NE, Heldin CH, et al: Identification of Smad7, a TGFbeta-inducible antagonist of TGF-beta signalling. Nature 389: 631-635, 1997.

41. Fujiwara M, Muragaki Y and Ooshima A: Upregulation of transforming growth factor-betal and vascular endothelial growth factor in cultured keloid fibroblasts: relevance to angiogenic activity. Arch Dermatol Res 297: 161-169, 2005.

42. Wu Y, Zhang Q, Ann DK, Akhondzadeh A, Duong HS, Messadi DV and Le AD: Increased vascular endothelial growth factor may account for elevated level of plasminogen activator inhibitor-1 via activating ERK1/2 in keloid fibroblasts. Am J Physiol Cell Physiol 286: C905-C912, 2004.

43. He S, Yang Y, Liu X, Huang W, Zhang X, Yang S and Zhang X: Compound Astragalus and Salvia miltiorrhiza extract inhibits cell proliferation, invasion and collagen synthesis in keloid fibroblasts by mediating transforming growth factor- $\beta /$ Smad pathway. Br J Dermatol 166: 564-574, 2012.

44. Tuan TL, Wu H, Huang EY, Chong SS, Laug W, Messadi D, Kelly $\mathrm{P}$ and Le A: Increased plasminogen activator inhibitor-1 in keloid fibroblasts may account for their elevated collagen accumulation in fibrin gel cultures. Am J Pathol 162: 1579-1589, 2003.

This work is licensed under a Creative Commons Attribution-NonCommercial-NoDerivatives 4.0 International (CC BY-NC-ND 4.0) License. 